\title{
Solution Structure of Human Orexin-A: Regulator of Appetite and Wakefulness
}

\author{
Hai-Young Kim ${ }^{\dagger}$, Eunmi Hong ${ }^{\dagger}$, Jae-il Kim ${ }^{*}$ and Weontae Lee ${ }^{\dagger} *$ \\ Department of Biochemistry, College of Science, Yonsei University, Seoul 120-740, Korea \\ ‡Anygen Co., Kwangju 500-712, Korea
}

Received 30 October 2003, Accepted 24 February 2004

\begin{abstract}
Orexin-A and orexin-B (hypocretin-1 and hypocretin-2, respectively) are important hypothalamic neuro-peptides, which are encoded by a single mRNA transcript and stimulate food intake as well as regulate wakefulness. Here we determined the solution structure of orexin-A by NMR spectroscopy and by simulated-annealing calculation. The structural features of orexin-A involve two $\alpha$-helices, with the hydrophobic residues disposed to on one side of helix, and hydrophilic residues to the other. A hydrophilic turn induced by two disulfide bonds provides the key difference between orexin-A and -B. With previous mutagenic studies, the derived structure of orexin-A provides us with a structure-functional view for novel drug design.
\end{abstract}

Keywords: Neuropeptide, NMR, Obesity, Orexin-A, Solution structure

\section{Introduction}

The most abundant mammalian neuro-peptides characterized to date are involved in a multiplicity of the physiological functions, namely, thermoregulation, obesity, blood pressure, cardiovascular system (Murphy et al., 1983; De Wied et al., 1991; Smith et al., 1992; Li et al., 1996; Fan et al., 1997; de Lecea et al., 1998; Sakurai et al., 1998; Willie et al., 2001). It

\footnotetext{
Abbreviations: NMR, nuclear magnetic resonance; CD, circular dichroism; NOE, nuclear overhauser effect; DG, distance geometry; SA, simulated-annealing; REM, restraint energy minimization; RMSD, root-mean-square deviation; TOCSY, total correlation spectroscopy; DQF-COSY, double quantum filtered correlation spectroscopy; $h \mathrm{OX} 1 \mathrm{R}$, human orexin-1 receptor; $h \mathrm{OX} 2 \mathrm{R}$, human orexin-2 receptor
}

*To whom correspondence should be addressed.

Tel: 82-2-2123-2706; Fax: 82-2-363-2706

E-mail: wlee@ spin.yonsei.ac.kr has been reported that the peptides orexin-A and orexin-B (also called hcrt-1 and hcrt-2) are involved in a number of cell signal-transduction pathways, for example, feeding behavior and energy homeostasis (Sakurai et al., 1998; de Lecea et al., 1998). Feeding behavior depends on a multiplex of metabolic, autonomic, endocrine, and environmental factors, which are coordinated by an appropriate state of cortical arousal (wakefulness). It has been reported that since orexin peptides have something to do with the sleep cycle, that a deficiency of orexin peptides generates narcoleptic symptoms (Willie et al., 2001).

The mRNA of the precursor of these orexins was specifically found in the lateral hypothalamus and adjacent areas, which are extensively involved in the integrated processes that regulate feeding behavior and energy homeostasis (Bernardis et al., 1993; Bernardis et al., 1996). However, a recent report demonstrated orexin-A expression in human peripheral tissues (Nakabayashi et al., 2003). The orexin peptides are produced by the proteolytic cleavage of an oligo-peptide precursor, prepro-orexin, and both $\mathrm{N}$-terminal pyroglutamyl cyclic forms, orexin- $\mathrm{A}$ and $\mathrm{C}$, which are terminal amidation variants of these two peptides, are frequently found as post-translational modification products. Orexin-A, a 33-residue peptide, contains two disulfide bonds, whereas orexin-B, a 28-residue peptide, does not possess a cysteine residue, even though it has $46 \%$ sequence identity with orexin-A (Fig. 1). Vertebrate orexin peptides show high sequence homology. Orexin peptides cloned from the amphibian Xenopus laevis were found to have high sequence homology with their mammalian counterparts (Willie et al., 2001). In addition, both human and rat orexin receptors have been recognized as members of the seven-transmembrane protein family of orphan G-protein-coupled cell surface receptors (Sakurai et al., 1998).

Orexin peptides stimulate food consumption and their production is regulated by nutritional state. NMR studies on several neuro-peptides have already provided convincing evidence concerning the importance of structure in the central 

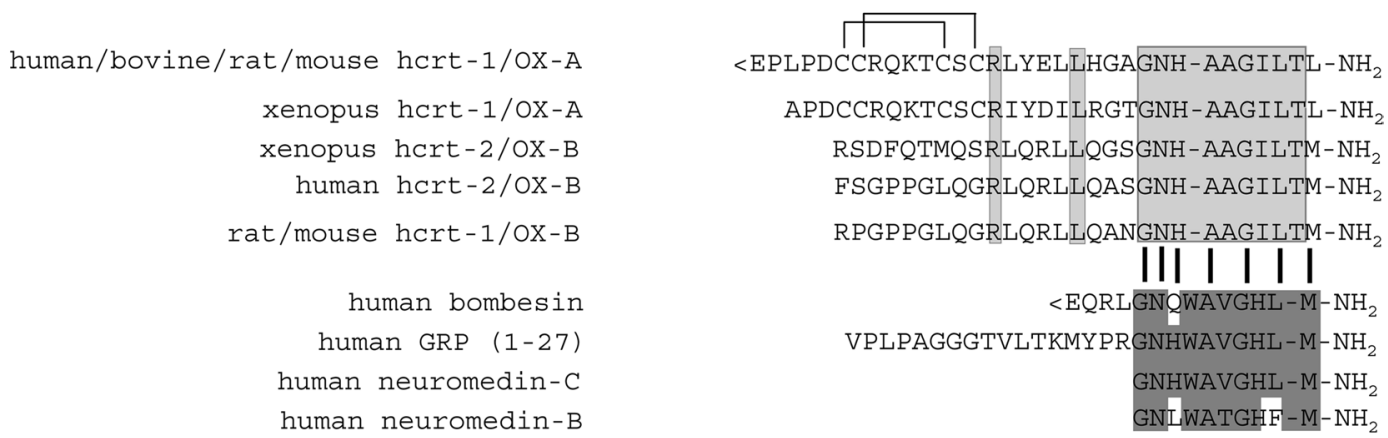

Fig. 1. Alignment of the amino acid sequences of hypocretins/orexins and of the bombesin family residue in the carboxy-terminus. The topologies of the two disulfide bonds in human orexin-A are indicated on the sequence. Identical residues are boxed. The N-terminus of human orexin-A is a pyroglutamyl residue $(<\mathrm{E})$.

regulation of obesity and energy balance (Darbon et al., 1992; Monks et al., 1996). We previously reported that human orexin-B forms two $\alpha$-helices connected by a small linker (Lee et al., 1999). Here, we present the three-dimensional solution structure of human orexin-A as determined by twodimensional NMR spectroscopy and dynamical simulatedannealing calculation. In terms of comparing it with the human orexin-B structure, we describe the characteristics of the human orexin-A structure-function relationship. This study adds information on the structure-function relationships of orexin-A, and provides a structural background for further ligand-receptor recognition studies on orexin neuropeptides.

\section{Materials and methods}

Peptide synthesis and purification Human orexin-A(Ac-Glu ${ }^{1}-$ Pro $^{2}-$ Leu $^{3}-$ Pro $^{4}-$ Asp $^{5}-\mathrm{Cys}^{6}-\mathrm{Cys}^{7}-\mathrm{Arg}^{8}-\mathrm{Gln}^{9}-\mathrm{Lys}^{10}-\mathrm{Thr}^{11}-\mathrm{Cys}^{12}-\mathrm{Ser}^{13}-$ $\mathrm{Cys}^{14}-\mathrm{Arg}^{15}-\mathrm{Leu}^{16}-\mathrm{Tyr}^{17}-\mathrm{Glu}^{18}-\mathrm{Leu}^{19}-\mathrm{Leu}^{20}-\mathrm{His}^{21}-\mathrm{Gly}^{22}-\mathrm{Ala}^{23}-\mathrm{Gly}^{24}-$ $\mathrm{Asn}^{25}-\mathrm{His}^{26}-\mathrm{Ala}^{27}-\mathrm{Ala}^{28}-\mathrm{Gly}^{29}-\mathrm{Ile}^{30}-\mathrm{Leu}^{31}-\mathrm{Thr}^{32}-\mathrm{Leu}^{33}-\mathrm{NH}_{2}$ ) was synthesized commercially (Anygen Co., Kwangju, Korea). The linear resin-bound peptide was synthesized as described above with Cys (Acm) in positions 6 and 12 and Cys (Trt) in positions 7 and 14. The synthetic peptide was purified by reverse-phase liquid chromatography using a Shim-Pack C18 column on a Water Delta Prep 4000 system. The disulfide bonded form of the peptide was characterized by the combined use of HPLC and MALDI-TOF mass spectrometry and confirmed by NMR spectroscopy: $\beta \beta$ NOE between disulfide-bonded cysteine residues shown in Fig. 1 (Werner et al., 1993).

Circular dichroism spectroscopy $\quad \mathrm{CD}$ spectra of $80 \mu \mathrm{M}$ human orexin-A were measured in $50 \mathrm{mM}$ potassium phosphate buffer at various $\mathrm{pHs}$, temperatures, and micelle conditions using a Jasco J810 spectropolarimeter. CD spectra were recorded from 190 to $250 \mathrm{~nm}$ at a scanning rate of $50 \mathrm{~nm} / \mathrm{min}$ with a time constant of $0.5 \mathrm{sec}$. Each CD spectrum was obtained by averaging 10 recordings with a step resolution of $0.2 \mathrm{~nm}$ and a bandwidth of $2.0 \mathrm{~nm}$ in cells with $0.1 \mathrm{~mm}$ path length (Koo et al., 2002).

NMR spectroscopy NMR was performed upon $2 \mathrm{mM}$ of the peptide in $50 \mathrm{mM}$ potassium phosphate buffer at $\mathrm{pH} 7.0$ in $100 \%$
$\mathrm{D}_{2} \mathrm{O}$ and $90 \% \mathrm{H}_{2} \mathrm{O} / 10 \% \mathrm{D}_{2} \mathrm{O}$. NMR spectra were recorded at 278 $\mathrm{K}$ on Bruker DRX-500 and DRX-600 spectrometers equipped with a triple-resonance probe and an $\mathrm{x}, \mathrm{y}, \mathrm{z}$-shielded pulsed-field
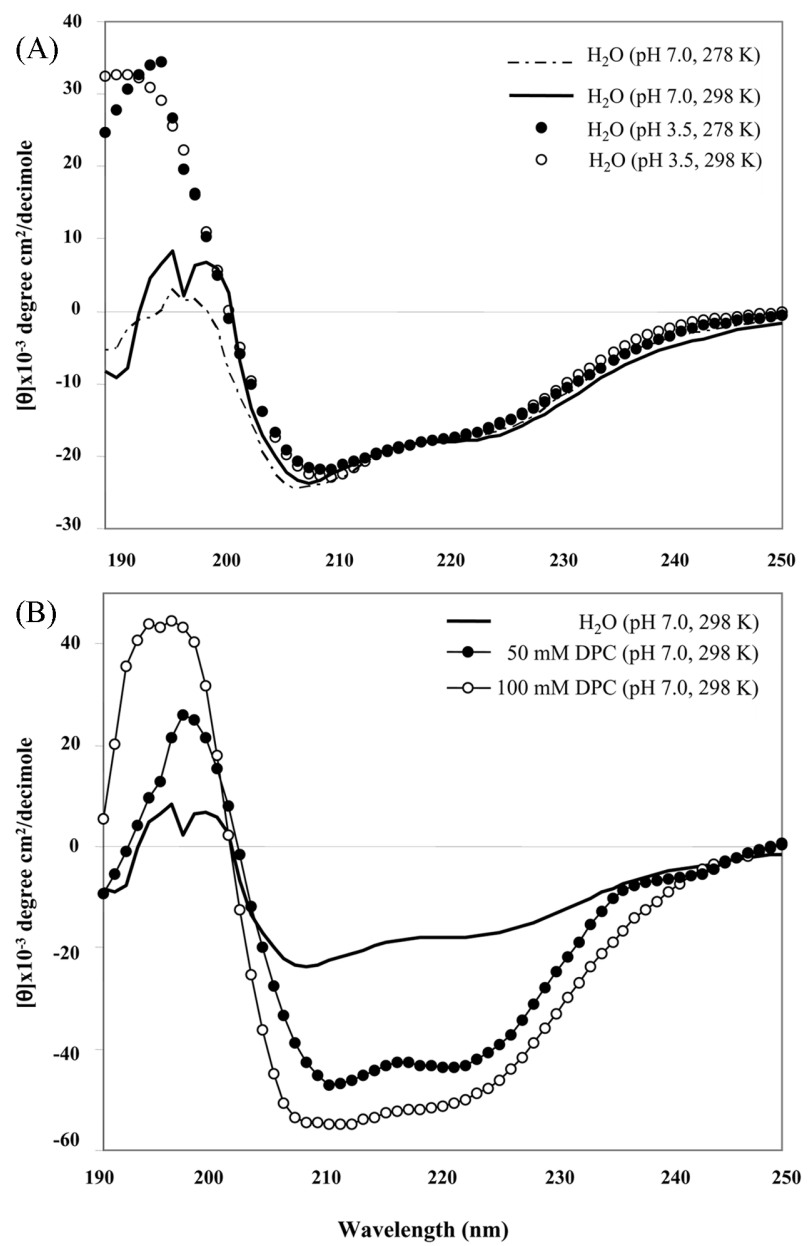

Fig. 2. Circular dichroism spectra of human orexin-A in various conditions; (A) $\mathrm{H}_{2} \mathrm{O}$ at $\mathrm{pH} 7.0,278 \mathrm{~K}$ (dash line), $\mathrm{H}_{2} \mathrm{O}$ at $\mathrm{pH}$ 7.0, $298 \mathrm{~K}$ (black line), $\mathrm{H}_{2} \mathrm{O}$ at $\mathrm{pH} 3.5,278 \mathrm{~K}$ (closed circle), $\mathrm{H}_{2} \mathrm{O}$ at $\mathrm{pH} 3.5,298 \mathrm{~K}$ (open circle). (B) $\mathrm{H}_{2} \mathrm{O}$ at $\mathrm{pH} 7.0,298 \mathrm{~K}$ (black line), $50 \mathrm{mM}$ DPC at $\mathrm{pH} 7.0,298 \mathrm{~K}$ (closed circle and line), $100 \mathrm{mM} \mathrm{DPC}$ at $\mathrm{pH} 7.0,298 \mathrm{~K}$ (open circle and line). 
gradient coil. Two-dimensional (2D) NMR spectra were recorded in the phase-sensitive mode using time-proportional phase incrementation (Marion et al., 1983) for quadrature detection in the $t_{1}$ domain. 2D experiments were performed using doublequantum-filtered COSY (DQF-COSY) (Rance et al., 1983), TOCSY (Davis et al., 1985) using a MLEV-17 spin-lock pulse sequence and a mixing time of $69.7 \mathrm{~ms}$, and NOESY (Jeener et al., 1979) with mixing times of 200, 300, 400, $600 \mathrm{~ms}$. For the DQF-COSY experiments, solvent suppression was performed by selective low-power irradiation of water resonance during the 2.0 $\mathrm{s}$ of relaxation delay. Solvent suppression for TOCSY and NOESY was achieved using a WATERGATE pulse sequence (Piotto et al., 1992) combined with a pulsed-field gradient pulse. All NMR spectra were acquired with 2048 complex data points in the $t_{2}$ and 256 increments in the $t_{1}$ dimension, with 32 scans per increment. Slowly exchanging amide protons were identified by lyophilizing fully protonated samples in $\mathrm{H}_{2} \mathrm{O}$ solutions, redissolving these in $100 \% \mathrm{D}_{2} \mathrm{O}$, and immediately acquiring a series of one-dimensional NOESY and 2D-NOESY spectra. ${ }^{3} J_{\mathrm{HN} \alpha}$ coupling constants were determined from 2D-DQF-COSY spectra, and strip-transformed to $8 \mathrm{~K} \times 1 \mathrm{~K}$.

All NMR data were processed on a Silicon Graphics Indigo II workstation using nmrPipe/nmrDraw (Delaglio et al., 1995) or XWIN-NMR (Bruker Instruments, Karlsruhe, Germany) software and analyzed using the Sparky 3.60 program (Goddard et al., 2003). Proton chemical shifts were expressed relative to the methyl resonance of internal sodium 2, 2-dimethyl-2-silapentane5-sulfonic acid (DSS).

Structural restraints and structure calculations Distance restraints were derived from NOESY spectra in $90 \% \mathrm{H}_{2} \mathrm{O} / 10 \%$ $\mathrm{D}_{2} \mathrm{O}$ solution. A total of 211 NOE constraints, 16 backbone

Table 1. Proton NMR chemical shift assignments for human orexin-A in $90 \% \mathrm{H}_{2} \mathrm{O} / 10 \% \mathrm{D}_{2} \mathrm{O}$ solution

\begin{tabular}{|c|c|c|c|c|}
\hline Residues & $\mathrm{NH}$ & $\mathrm{C}^{\alpha} \mathrm{H}$ & $\mathrm{C}^{\beta} \mathrm{H}$ & Others \\
\hline Glu1 & 7.707 & 3.964 & 1.653 & $\mathrm{C}^{\gamma} \mathrm{H}_{2}(2.094)$ \\
\hline Pro2 & & 4.161 & 1.980 & $\mathrm{C}^{\gamma} \mathrm{H}_{2}(1.710,1.587) \mathrm{C}^{\delta} \mathrm{H}_{3}(3.441)$ \\
\hline Leu3 & 8.208 & 4.243 & 1.191 & $\mathrm{C}^{\gamma} \mathrm{H}(1.191) \mathrm{C}^{\delta} \mathrm{H}_{3}(0.623)$ \\
\hline Pro4 & & 4.155 & 1.980 & $\mathrm{C}^{\gamma} \mathrm{H}_{2}(1.724,1.592) \mathrm{C}^{\delta} \mathrm{H}_{3}(3.408)$ \\
\hline Asp5 & 7.789 & 4.281 & $2.462,2.362$ & \\
\hline Cys6 & 7.858 & 4.053 & 2.816 & \\
\hline Cys7 & 8.910 & 4.492 & 2.998 & \\
\hline Arg8 & 8.284 & 3.931 & 1.482 & $\mathrm{C}^{\gamma} \mathrm{H}_{2}(1.282) \mathrm{C}^{\delta} \mathrm{H}_{2}(2.904) \mathrm{N}_{2} \mathrm{H}(7.412,6.714)$ \\
\hline Gln9 & 8.166 & 4.264 & 1.575 & $\mathrm{C}^{\gamma} \mathrm{H}_{2}(2.033) \mathrm{N}^{\delta} \mathrm{H}_{2}$ \\
\hline Lys10 & 7.757 & 3.944 & 1.243 & $\mathrm{C}^{\gamma} \mathrm{H}_{2}(1.019) \mathrm{C}^{\delta} \mathrm{H}_{2}(2.979) \mathrm{C}^{\varepsilon} \mathrm{H}_{2} \mathrm{~N}^{\varepsilon} \mathrm{H}_{3}^{+}(7.944)$ \\
\hline Thr11 & 8.139 & 4.043 & 3.659 & $\mathrm{C}^{\gamma} \mathrm{H}_{3}(1.107)$ \\
\hline Cys 12 & 7.434 & 3.762 & 2.494 & \\
\hline Ser13 & 8.457 & 4.158 & 3.575 & \\
\hline Cys14 & 8.498 & 4.201 & 2.356 & \\
\hline $\operatorname{Arg} 15$ & 7.674 & 3.798 & 1.653 & $\mathrm{C}^{\gamma} \mathrm{H}_{2}(1.362) \mathrm{C}^{\delta} \mathrm{H}_{2}(2.909) \mathrm{NH}_{2}(6.615,7.316)$ \\
\hline Leu16 & 8.231 & 4.174 & 1.334 & $\mathrm{C}^{\gamma} \mathrm{H}(1.334) \mathrm{C}^{\delta} \mathrm{H}_{3}(0.597)$ \\
\hline Tyr17 & 7.982 & 4.353 & $2.901,2.570$ & $2,6 \mathrm{H}(7.412) 3,5 \mathrm{H}(6.938)$ \\
\hline Glu18 & 8.057 & 3.727 & 1.765 & $\mathrm{C}^{\gamma} \mathrm{H}_{2}(2.054)$ \\
\hline Leu19 & 7.801 & 3.907 & 1.544 & $\mathrm{C}^{\gamma} \mathrm{H}(1.279) \mathrm{C}^{\delta} \mathrm{H}_{3}(0.874,0.573)$ \\
\hline Leu20 & 7.801 & 3.907 & 1.544 & $\mathrm{C}^{\gamma} \mathrm{H}(1.279) \mathrm{C}^{\delta} \mathrm{H}_{3}(0.874,0.573)$ \\
\hline His 21 & 7.614 & 4.276 & 2.801 & $2 \mathrm{H}(7.864) 4 \mathrm{H}(6.843)$ \\
\hline Gly22 & 8.406 & 4.087 & & \\
\hline Ala23 & 8.289 & 4.335 & 1.051 & \\
\hline Gly24 & 8.303 & 3.656 & & \\
\hline Asn 25 & 8.080 & 4.416 & 2.449 & $\mathrm{~N}^{\gamma} \mathrm{H}_{2}$ \\
\hline His26 & 8.222 & 4.380 & 2.870 & $2 \mathrm{H}(7.783) 4 \mathrm{H}(6.615)$ \\
\hline Ala27 & 8.322 & 4.239 & 1.245 & \\
\hline Ala28 & 7.955 & 3.896 & 1.255 & \\
\hline Gly29 & 8.530 & 4.276 & & \\
\hline Ile30 & 7.479 & 4.073 & 1.902 & $\mathrm{C}^{\gamma} \mathrm{H}_{2}(1.757) \mathrm{C}^{\gamma} \mathrm{H}_{3}(1.482) \mathrm{C}^{\delta} \mathrm{H}_{3}(1.097)$ \\
\hline Leu31 & 8.110 & 4.064 & 1.339 & $\mathrm{C}^{\gamma} \mathrm{H}(1.339) \mathrm{C}^{\delta} \mathrm{H}_{3}(0.581)$ \\
\hline Thr32 & 7.997 & 4.116 & 3.927 & $\mathrm{C}^{\gamma} \mathrm{H}_{3}(0.875)$ \\
\hline Leu33 & 8.110 & 4.064 & 1.339 & $\mathrm{C}^{\gamma} \mathrm{H}(1.339) \mathrm{C}^{\delta} \mathrm{H}_{3}(0.581)$ \\
\hline
\end{tabular}

Chemical shifts are expressed in p.p.m. relative to internal 2, 2-dimethyl-2-siapentane-5-sulfonate.

The sample was maintained at $5^{\circ} \mathrm{C}$ and $\mathrm{pH}$ 7.0. 
dihedral angles, and 8 hydrogen-bond restraints were used. Crosspeak volumes were classified as strong, medium, or weak, corresponding to upper bound interproton distance restraints of 2.7, 3.3 and 5.0 , respectively (Cho et al., 2003). Backbone dihedral restraints inferred from ${ }^{3} J_{\mathrm{HN} \alpha}$ coupling constants were used as $-55 \pm 5^{\circ}$ for a ${ }^{3} J_{\mathrm{HNa}}$ of less than $6 \mathrm{~Hz}$ (Wagner et al., 1987; Driscoll et al., 1989). Three-dimensional structures were calculated using hybrid distance geometry and the dynamic simulated annealing protocol, as previously described (Nilges et al., 1988a; Nilges et al., 1988b; Nilges et al. 1988c; Driscoll et al., 1989), using the CNS 1.0 program on a SGI Indigo ${ }^{2}$ workstation. The methodology employed was similar to the original protocol of Lee et al. (1994). Final structures were analyzed using PROCHECK (Lakovski et al., 1993) and displayed using the Insight II (Accelrys Inc., San Diego, USA) and MOLMOL programs (Koradi et al., 1996).

\section{Results and Discussion}

Circular dichroism spectroscopy $\mathrm{CD}$ spectra of human orexin-A were acquired at various $\mathrm{pHs}$, temperatures, and solvent conditions. CD spectra in aqueous solutions were measured at a peptide concentration of $80 \mu \mathrm{M}$ in $50 \mathrm{mM}$ potassium phosphate. Fig. 2A shows that orexin-A contains a helical conformation in a physiological environment $(\mathrm{pH} 7.0$, $298 \mathrm{~K}$ ) by ellipticity at $222 \mathrm{~nm}$. $\mathrm{pH}$ and temperature differences were not significant factors of helicity. However, in membrane mimetic conditions (in DPC) the helicity of human orexin-A increased (Fig. 2B). From the above results samples in $90 \% \mathrm{H}_{2} \mathrm{O} / 10 \% \mathrm{D}_{2} \mathrm{O}(\mathrm{pH} 7.0)$ and in $50 \mathrm{mM} \mathrm{DPC/}$ $90 \% \mathrm{H}_{2} \mathrm{O} / 10 \% \mathrm{D}_{2} \mathrm{O}$ (pH 7.0) solution were prepared for NMR experiments. But since the sample in $50 \mathrm{mM}$ DPC solution showed problems like line broadening and an insufficient number of peaks in the TOCSY spectrum, only the sample in the physiological environment $\left(90 \% \mathrm{H}_{2} \mathrm{O} / 10 \% \mathrm{D}_{2} \mathrm{O}, \mathrm{pH} 7.0\right.$, $278 \mathrm{~K}$ ) was used for NMR.

NMR resonance assignments and secondary structures Complete proton resonance assignments for human orexin-A were achieved using the standard sequential resonance assignment procedure. Once the individual spin systems had been classified, the backbone sequential resonance assignment was completed by $d_{\alpha \mathrm{N}}(i, i+1)$ NOE connectivities in the 2DNOESY spectrum. The chemical shifts of orexin-A are listed in Table 1 (BMRB code: 5994). A number of well-resolved intense $d_{\mathrm{NN}}$ cross-peaks from Cys ${ }^{12}$ to $\mathrm{Thr}^{32}$ were observed, suggesting the presence of an $\alpha$-helix. Figure 3 summarizes the sequential and short-range NOE connectivities observed for human orexin- $\mathrm{A}$ in $\mathrm{H}_{2} \mathrm{O}$ solution. The observations of continuous $d_{\mathrm{NN}}(i, i+1)$ contacts and the characteristic $d_{\alpha \mathrm{N}}(i$, $i+3)$ and $d_{\alpha \beta}(i, i+3)$ NOEs strongly support the existence of a-helices comprised of residues $\mathrm{Cys}^{14}-\mathrm{His}^{21}$ (helix I) and

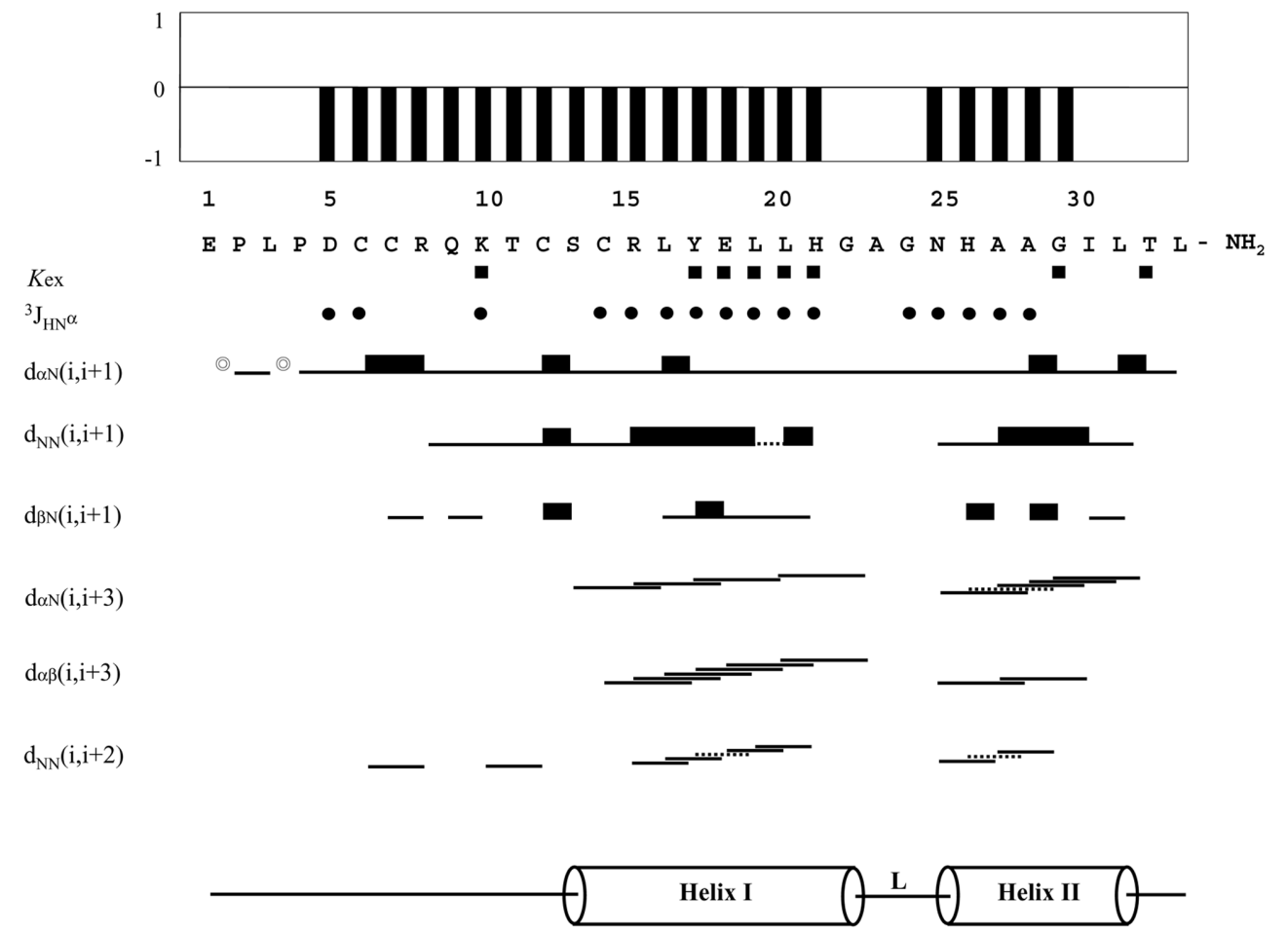

Fig. 3. Summary of NMR data for human orexin-A collected in $\mathrm{H}_{2} \mathrm{O}$, at $278 \mathrm{~K}$, showing sequential and short-range NOE contacts. Slowly exchanging amide protons ( $)$, backbone vicinal coupling constants $\left(\mathbf{O} ;{ }^{3} \mathrm{JN}_{\mathrm{HN} \alpha}<6 \mathrm{~Hz}\right.$ ), and chemical shift indices (CSI) for the $\mathrm{C}_{\alpha \mathrm{H}}$ chemical shift are indicated. () represents the proline residues that have been assigned to be trans-conformers based on characteristic $d_{\alpha \delta}(\mathrm{i}, \mathrm{i}+1)$ NOEs. The dashed line represents the ambiguous NOEs from the resonance overlapping. 
$\mathrm{Asn}^{25}-\mathrm{Leu}^{31}$ (helix II) in $\mathrm{H}_{2} \mathrm{O}$ solution. In particular, most $d_{\alpha \mathrm{N}}$ $(i, i+3)$ and $d_{\mathrm{NN}}(i, i+2)$ NOEs were observed for helix I and helix II. This result is further supported by the small ${ }^{3} J_{\mathrm{HN}}$ coupling constants, backbone amid-proton exchange data (Wishart et al., 1992), and chemical shift index values (Kane et al., 2000). The N-terminal $\mathrm{Asp}^{5}-\mathrm{Thr}^{13}$ region was first predicted to be a helix by CSI data, and this was supported by a rigid turn conformation induced by disulfides bonds between $\mathrm{Cys}^{6}$ and $\mathrm{Cys}^{12}$, $\mathrm{Cys}^{7}$ and $\mathrm{Cys}^{14}$ was then found by structure calculation.

Structure-function of human orexin-A The NMR structure

Table 2. Structural statistics for the 20 final simulated-annealing structures of human orexin-A

\begin{tabular}{|c|c|c|}
\hline & $\langle\mathrm{SA}\rangle_{\mathrm{k}}$ & $\langle\overline{\mathrm{SA}}\rangle_{\mathrm{kr}}$ \\
\hline $\begin{array}{l}\text { (A) rmsd from experimental distance restraints }(\AA) \\
\text { all }(211) \\
\text { sequential }(|\mathrm{i}-\mathrm{j}|=1)(78) \\
\text { short range }(1<|\mathrm{i} \mathrm{j}| \leq 5)(38) \\
\text { intra residue }(95) \\
\text { hydrogen bond (8) }\end{array}$ & $\begin{array}{l}0.0196 \\
0.0152 \\
0.0156 \\
0.0212 \\
0.0122\end{array}$ & $\begin{array}{l}0.0212 \\
0.0203 \\
0.0130 \\
0.0242 \\
0.0046\end{array}$ \\
\hline $\begin{array}{l}\text { (B) rmsd from experimental dihedral restraints (deg ) } \\
\text { dihedral restraints (deg) }\end{array}$ & 0.0820 & 0.1547 \\
\hline 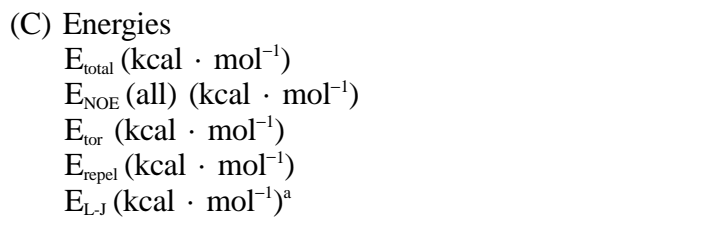 & $\begin{array}{r}42.22 \\
6.76 \\
22.42 \\
10.08 \\
-121.761\end{array}$ & $\begin{array}{r}37.97 \\
7.58 \\
20.21 \\
7.79 \\
-130.749\end{array}$ \\
\hline $\begin{array}{l}\text { (D) Deviations from idealized covalent geometry } \\
\text { bonds }(\AA) \\
\text { angles }(\mathrm{deg}) \\
\text { impropers }(\mathrm{deg})\end{array}$ & $\begin{array}{l}0.0019 \\
0.4013 \\
0.1544\end{array}$ & $\begin{array}{l}0.0020 \\
0.3823 \\
0.1075\end{array}$ \\
\hline (E) Atomic rmsds & Backbone atoms (nm) & $\begin{array}{l}\text { All atoms } \\
(\mathrm{nm})\end{array}$ \\
\hline$\langle\mathrm{SA}\rangle_{\mathrm{k}}$ vS $\langle\overline{\mathrm{SA}}\rangle_{\mathrm{k}}$ & $0.039(0.047)$ & $0.157(0.142)$ \\
\hline$\langle\overline{\mathrm{SA}}\rangle_{\mathrm{kr}}$ vs $\langle\overline{\mathrm{SA}}\rangle_{\mathrm{k}}$ & $0.020(0.046)$ & $0.106(0.091)$ \\
\hline$\langle\mathrm{SA}\rangle_{\mathrm{k}} \mathrm{VS}\langle\overline{\mathrm{SA}}\rangle_{\mathrm{kr}}$ & $0.039(0.049)$ & $0.151(0.143)$ \\
\hline
\end{tabular}

$\langle\mathrm{SA}\rangle_{\mathrm{k}},\langle\overline{\mathrm{SA}}\rangle_{\mathrm{k},}$ and $\langle\overline{\mathrm{SA}}\rangle_{\mathrm{kr}}$ denote simulated-annealing structures, average structure of 20 calculated structures, and average restraint energy minimization structure, respectively.

${ }^{a} \mathrm{E}_{\mathrm{L}-\mathrm{J}}$ is the Lennard-Jones/Van der Waals potential calculated using CHARMm empirical energy function.

${ }^{b}$ Values calculated in the $\mathrm{Cys}^{14}-\mathrm{His}^{21}$ and $\mathrm{Asn}^{25}-\mathrm{Leu}^{31}$ ranges are in parentheses.
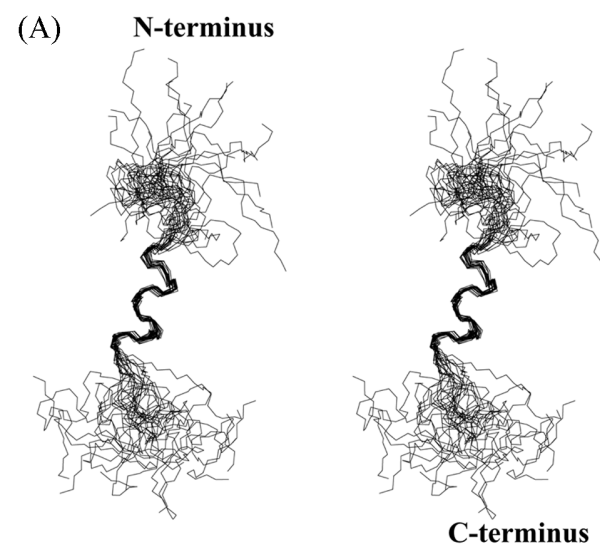

(B)
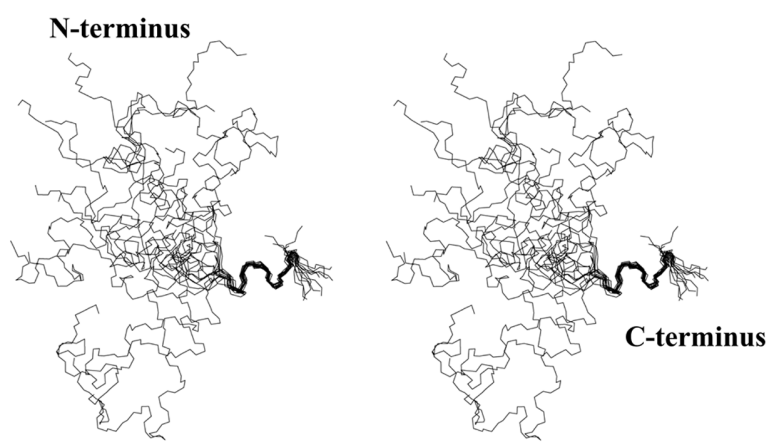

Fig. 4. Superimposition of the backbone atoms of 20 structures ( $\mathrm{C}^{\alpha}$ traces). The structures of human orexin-A were aligned for the best overlap of residues (A) 14-21 (Helix I) (B) 25-31 (Helix II), respectively. 

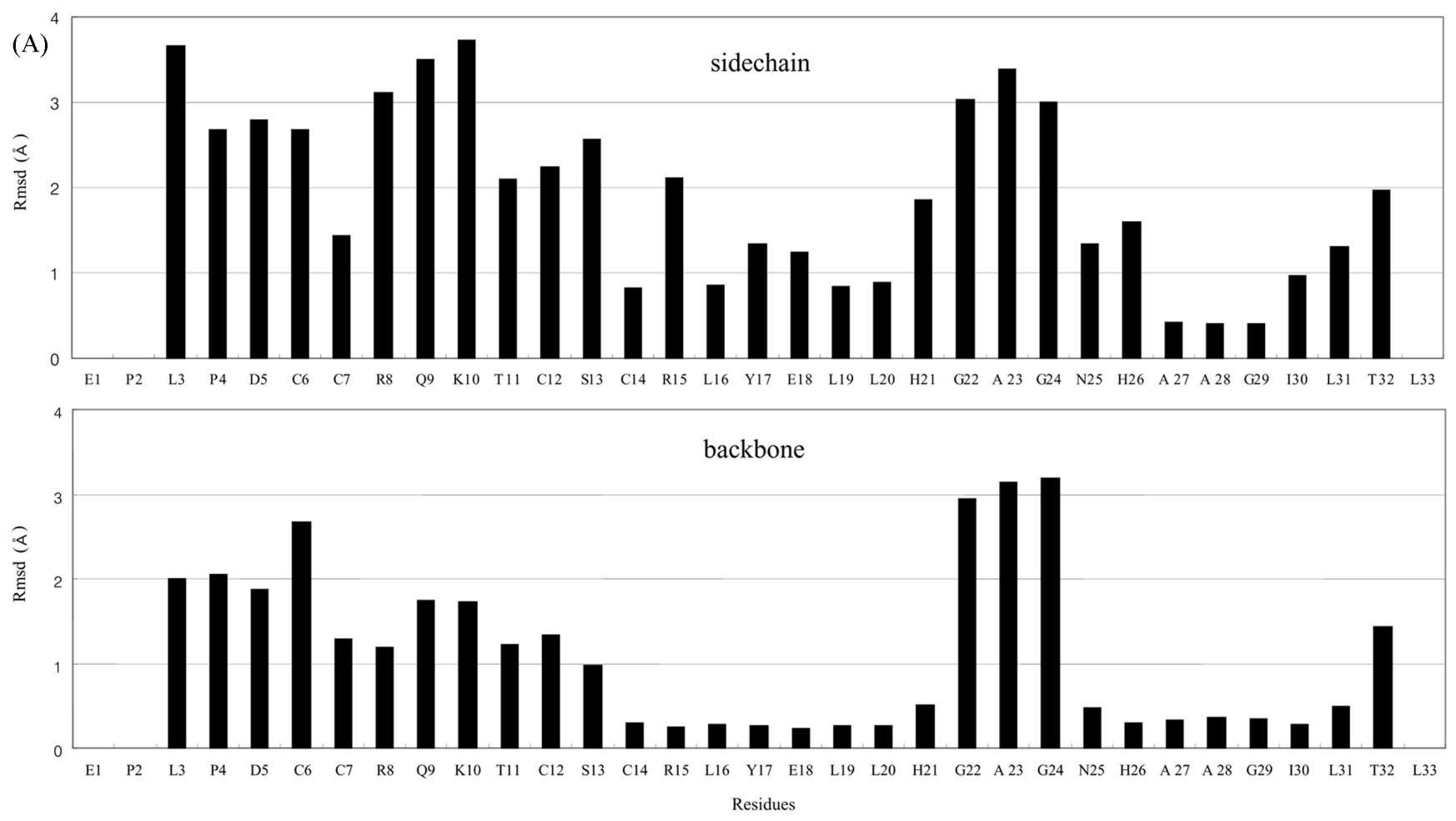

(B)

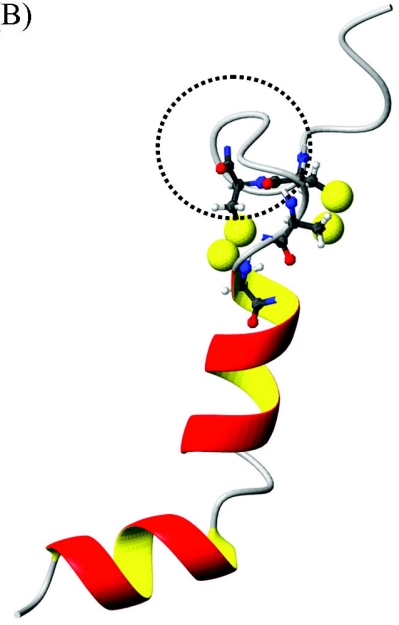

Fig. 5. (A) Atomic distribution of the average rmsds of the backbone and sidechain atoms in the 20 final simulated-annealing structures of human orexin-A. Deviations were calculated from the mean structure for the human orexin-A at pH 7.0, $278 \mathrm{~K}$. (B) The average $\mathrm{REM}$ ribbon drawing structure of human orexin- $\mathrm{A}$ in $\mathrm{H}_{2} \mathrm{O}$. The figure was generated using the MOLMOL program. Grey circles were represented s-s bond and dashed line showed RQKT loop.

of human orexin-A (PDB code: 1R02) was calculated using the experimental restraints derived from 2D-NOESY and DQF-COSY spectra collected at $278 \mathrm{~K}$. A total of 50 distance geometry structures served as starting structures for dynamical simulated-annealing calculations for the peptide in $\mathrm{H}_{2} \mathrm{O}$ solutions. All 50 structures showed no restraint violations of greater than $0.5 \AA$ for distances and $3^{\circ}$ for torsion angles. The 20 lowest energy structures $\left(\langle\mathrm{SA}\rangle_{\mathrm{k}}\right)$ of the 50 simulatedannealing structures were selected for detailed structural analysis. The average structure $\left(\langle\overline{\mathrm{SA}}\rangle_{\mathrm{k}}\right)$ was calculated from the geometrical average of $20\langle\mathrm{SA}\rangle_{\mathrm{k}}$ structure coordinates, and this was subjected to restraint energy minimization to correct covalent bonds and angle distortions. Table 2 summarizes the statistics of the final structures. The Ramachandran plot (not shown) for all $20\langle\mathrm{SA}\rangle_{\mathrm{k}}$ structures showed that the $\phi, \psi$ angles of the final simulated-annealing structures were distributed properly in energetically acceptable regions. PROCHECK analysis then showed that all residues were in allowed regions of the Ramachandran map. The energies and structural statistics of the $20\langle\mathrm{SA}\rangle_{\mathrm{k}}$ and the 
$\langle\overline{\mathrm{SA}}\rangle_{\mathrm{kr}}$ structure are listed in Table 2 . A best-fit superposition of the $20\langle\mathrm{SA}\rangle_{\mathrm{k}}$ structures and the energy-minimized average structure $\left(\langle\overline{\mathrm{SA}}\rangle_{\mathrm{kr}}\right)$ is shown in Fig. 4A, B. In Fig. 5A, the atomic rmsds of the final 20 structures for the individual residues are displayed with respected to the average structure $(<\mathrm{SA}>\mathrm{k})$.

The main structural features of human orexin-A are two ahelices spanning residues Cys ${ }^{14}-\mathrm{His}^{21}$ (helix I) and $\mathrm{Asn}^{25}-\mathrm{Leu}^{31}$ (helix II) in solution. Helix I was observed to be more compact than helix II. The two $\alpha$-helices are connected by a flexible loop. The structure contains two intramolecular disulfide bonds between residues $\mathrm{Cys}^{6}$ and $\mathrm{Cys}^{12}$, and $\mathrm{Cys}^{7}$ and $\mathrm{Cys}^{14}$ in its $\mathrm{N}$-terminus (Fig. 5B) and these bonds make a rigid turn conformation between the $\mathrm{Arg}^{8}-\mathrm{Thr}^{11}$ residues. Human orexin-A and human orexin-B have similar structures, so orexin receptors bind both orexin peptides (Kane et al., 2000). On comparing the two peptide structures, the residues of the $\mathrm{Cys}^{14} \mathrm{His}^{21}$ (helix I) of human orexin-A are well superposed with those of $\mathrm{Gly}^{9} \mathrm{Gly}^{16}$ of human orexin-B, showing an rmsd of $0.8 \AA$ for $\mathrm{C}^{\mathrm{a}}$ atoms.

Both receptors, $h \mathrm{OX} 1 \mathrm{R}$ (425 residues) and $h \mathrm{OX} 2 \mathrm{R}(444$ residues), belong to the class I subfamily within the superfamily of G-protein coupled receptors. They have identical conformations in the transmembrane, extra cellular loop, and the intra cellular loop 1, 2 regions. However, the Nterminal extra cellular domain, intracellular loop 3, and the Cterminal cytosolic domains have different conformations (Voisin et al., 2003). Thus, the N-terminal extra cellular domain of hOX1R might distinguish human orexin-A and human orexin-B. From studies on canine narcolepsy, the Cterminal region of human orexin- $\mathrm{A}$, a region identical with human orexin-B, is essential for $h \mathrm{OX} 2 \mathrm{R}$ activation (Wieland et al., 2002). However, in the case of human orexin-A, the binding affinity of human orexin-A without residues 1-14, showed 60 -fold lower affinity for $h \mathrm{OX} 1 \mathrm{R}$, and 23 -fold lower affinity for $h \mathrm{OX} 2 \mathrm{R}$. Human orexin-A without disulfide bonds showed similar results. These bonds were reported to play a key role in the stimulation of gastric acid secretion (Okumura et al., 2001). The rigid turn induced by the two disulfide bonds contains characteristic charged residues, RQKT. Although there is insufficient information about the interaction of this turn and receptors, it is apparent from a previous peptide mutation study (Voisin et al., 2003) that the $\mathrm{N}$-terminal extra cellular domain of $h \mathrm{OX} 1 \mathrm{R}$ might interact with the turn of human orexin-A and enhance the receptor binding affinity of human orexin-A. Moreover, breakage of these disulfide bonds might disrupt the turn conformation and induce lower binding human orexin-A affinity. In addition, a study of the E54K mutation in hOX2R (Hungs et al., 2001) suggested that the $\mathrm{N}$-terminal extra cellular domain of $h \mathrm{OX}$ receptors might also interact with the $\mathrm{C}$-terminal of orexin peptides. In conclusion, whereas the $\mathrm{C}$-terminal helix region of orexin peptides might be essential for interaction with $h \mathrm{OX}$ receptors, the $\mathrm{N}$-terminal region $\mathrm{Glu}^{1}-\mathrm{Cys}^{12}$, a rigid turn with a coil, of human orexin-A might potently increase its selectivity

\section{for $h \mathrm{OX} 1 \mathrm{R}$.}

The helical wheel diagram shows that the hydrophobic residues $\left(\mathrm{Leu}^{16}, \mathrm{Leu}^{19}\right.$, and $\left.\mathrm{Leu}^{20}\right)$ are positioned on one side of the helix, while the hydrophilic residues $\left(\mathrm{Cys}^{14}, \mathrm{Arg}^{15}, \mathrm{Tyr}^{17}\right.$, $\mathrm{Glu}^{18}$, and $\mathrm{His}^{21}$ ) are located on the other side. There is accumulating evidence that many hormones display amphiphilic secondary structures, mainly $\alpha$-helices. These kinds of amphiphilic peptides have the ability to selfaggregate or dimerize (Mirjam et al., 2002), but the data from the analytical ultra centrifuge analysis showed that the monomer form predominated under the NMR experimental condition.

Human neuropeptide Y, are orexin-like signaling peptide, is negatively regulated by leptin (Zarjevski et al., 1993; Stephens et al., 1995), and has been characterized as one of the positive regulators of feeding behavior. Monks et al. (1996) suggested that the monomeric human neuropeptide Y molecule could be associated with the hydrophobic side in the $\alpha$-helical region at high concentration, and that it might even form a dimer (Mirjam et al., 2002). But in our study, the monomeric form dominated and the structure of monomeric form was elucidated. It is interesting to note that the solution structure of human neuropeptide $\mathrm{Y}$ also contains a kink in the middle of amphiphilic helix (Monks et al., 1996). Schwartz et al. (1998) proposed that the orexins play a role analogous to that of neuropeptide $\mathrm{Y}$ in the control of energy balance. Even though orexins and neuropeptide $\mathrm{Y}$ share low sequence homology, we can presume that their similar biological functions stem from the structural homology between the two neuropeptides. Interestingly, the human orexin-A cappinghelix conformation induced by disulfide bonds extends duration of action versus neuropeptide Y (Willie et al., 2001).

In this study, we demonstrate the solution structure of human orexin-A and compared this with human orexin-B. Like other neuropeptides, its conformation shows an amphiphilic helix with a unique RQKT turn. In our future work, the interaction between orexin peptides and receptors will be further studied. We hope to obtain more detailed information on orexin-receptor interaction for novel drug development.

Acknowledgments This study was supported by the Korean Ministry of Science and Technology and the Korean Science and Engineering Foundation through the NRL program of MOST NRDP (M1-0203-00-0020).

\section{References}

Bernardis, L. L. and Bellinger, L. L. (1993) The lateral hypothalamic area revisited: Neuroanatomy, body weight regulation. Neurosci. Biobehav. Rev. 17, 141-193.

Bernardis, L. L. and Bellinger, L. L. (1996) The lateral hypothalamic area revisited: Ingestive behavior. Neurosci. Biobehav. Rev. 20, 189-287.

Cho, M. K., Kim, S. S., Lee, M. R., Shin, J., Lee, J., Lim, S. K., 
Baik, J. H., Yoon, C. J., Shin, I. and Lee, W. (2003) NMR studies on turn mimetic analogs derived from melanocytestimulating hormones. J. Biochem. Mol. Biol. 36, 552-557.

Darbon, H., Bernassau, J. -M., Deleuze, C., Chenu, J., Roussel, A. and Cambillau, C. (1992) Solution conformation of human neuropeptide $\mathrm{Y}$ by ${ }^{1} \mathrm{H}$ nuclear magnetic resonance and restrained molecular dynamics. Eur. J. Biochem. 209, 765-771.

Davis, D. G. and Bax, A. (1985) Assignment of complex ${ }^{1} \mathrm{H}$ NMR spectra via two-dimensional homonuclear HartmannHahn spectroscopy. J. Am. Chem. Soc. 107, 2820-2821.

Delaglio, F., Grzesiek, S., Vuister, G. W., Zhu, G., Pfeifer, J. and Bax, A. (1995) NMRPipe: a multidimensional spectral processing system based on UNIX pipes. J. Biomol. NMR, 6, 277-293.

Driscoll, P. C., Gronenborn, A. M. and Clore, G. M. (1989) The influence of stereospecific assignments on the determination of three-dimensional structures of proteins by nuclear magnetic resonance spectroscopy: Application to the sea anemone protein BDS-1. FEBS Lett. 243, 223-233.

Driscoll, P. C., Gronenborn, A. M., Beress, L. and Clore, G. M. (1989) Determination of the three-dimensional solution structure of the antihypertensive and antiviral protein BDS-1 from the sea anemone Anemonia sulcata: A study using nuclear magnetic resonance and hybrid distance geometrydynamical simulated annealing. Biochemistry 28, 2188-2198.

de Lecea, L., Kilduff, T. S., Peyron, C., Gao, X., Foye, P. E., Danielson, P. E., Fukuhara, C., Battenberg, E. L., Gautvik, V. T., Bartlett, F. S. 2nd, Frankel, W. N., van den Pol, A. N., Bloom, F. E., Gautvik, K. M. and Sutcliffe, J. G. (1998) The hypocretins: Hypothalamus-specific peptides with neuroexcitatory activity. Proc. Natl. Acad. Sci. USA 95, 322-327.

De Wied, D. and Croiset, G. (1991) Stress modulation of learning and memory processes. Methods Achieve Exp. Pathol. 15, 167199.

Fan, W., Boston, B. A., Kesterson, R. A., Hruby, V. J. and Cone, R. D. (1997) Role of melanocortigergic neurons in feeding and the agouti obesity syndrome. Nature $\mathbf{3 8 5}, 165-168$.

Goddard, D. and Kneller, D. G. (2003) SPARKY 3, University of California, San Francisco, http://www.cgl.ucsf.edu/home/sparky/

Hungs, M., Fan, J., Lin, L., Lin, X., Maki, R. A. and Mignot, E. (2001) Identification and functional analysis of mutations in the hypocretin (orexin) genes of narcoleptic canines. Genome Res. 11, 531-539.

Jeener, J., Meier, B. H., Bachman, P. and Ernst, R. R. (1979) Investigation of exchange processes by two-dimensional NMR spectroscopy. J. Chem. Phys. 71, 4546-4553.

Kane, J. K., Tanaka, H., Parker, S. L., Yanagisawa, M. and Li, M. D. (2000) Sensitivity of orexin-A binding to phospholipase C inhibitors, neuropeptide Y, and secretin. Biochem. Biophys. Res. Commun. 272, 959-965.

Koo, B. K., Kim, M. H., Lee, S. T. and Lee, W. (2002) Purification and spectroscopic characterization of the human protein tyrosine kinase-6 SH3 domain. J. Biochem. Mol. Biol. 35, 343-347.

Koradi, R., Billeter, M. and Wüthrich, K. (1996) MOLMOL: A program for display and analysis of macromolecular structures. J. Mol. Graphics 14, 51-55.

Lakovski, R. A., MacArthur, M. W., Moss, D. S. and Thornton, J. M. (1993) PROCHECK: A program to check the stereochemical quality of proteins structures. J. Appl. Crystallogr. 26, 283-291.
Lee, J.-H., Bang, E. J., Chae, K.-J., Kim, J. Y. Lee, D. W. and Lee, W. (1999) Solution structures of a new hypothalamic neuropeptide, human hypocretin-2/orexin-B. Eur. J. Biochem. 266, 831-839.

Lee, W., Moore, C. H., Watt, D. D. and Krishna, N. R. (1994) Solution structure of the variant-3 neurotoxin from Centruroides sculpturatus Ewing. Eur. J. Biochem. 218, 89-95.

Li, S. J., Varga, K., Archer, P., Hruby, V. J., Sharma, S. D., Kesterson, R. A., Cone, R. D. and Kunos, G. (1996) Melanocortin antagonists define two distinct pathways of cardiovascular control by $\alpha$ - and $\gamma$-melanocyte-stimulating hormones. J. Neurosci. 16, 5182-5188.

Marion, D. and Wuthrich, K. (1983) Application of phase sensitive two-dimensional correlated spectroscopy (COSY) for measurements of ${ }^{1} \mathrm{H}-{ }^{-} \mathrm{H}$ spin-spin coupling constants in proteins. Biochem. Biophys. Res. Commun., 113, 967-974.

Merutka, G., Dyson, H. J. and Wright, P. E. (1995) Random coil ${ }^{1} \mathrm{H}$ chemical shifts obtained as a function of temperature and trifluoroethanol concentration for the peptide series GGXGG. $J$. Biomol. NMR 5, 14-24.

Mirjam, L., Verena, G., Reto, B., Barbara, C., Gerd, F. and Oliver, Z. (2002) Bovine pancreatic polypeptide (bPP) undergoes significant changes in conformation and dynamics upon binding to DPC micelles. J. Mol. Biol. 3221117-1133.

Monks, S. A., Karagianis, G., Howlett, G. J. and Norton, R. S. (1996) Solution structure of human neuropeptide Y. J. Biomol. NMR 8, 379-390.

Murphy, M. T., Richards, D. B. and Lipton, J. M. (1983) Antipyretic potency of centrally administered $\alpha$-melanocyte stimulating hormone. Science 221, 192-193.

Nakabayashi, M., Suzuki, T., Takahashi, K., Totsune, K., Muramatsu, Y., Kaneko, C., Date, F., Takeyama, J., Darnel, A. D., Moriya, T. and Sasano, H. (2003) Orexin-A expression in human peripheral tissues. Mol Cell Endocrinol. 205, 43-50.

Nilges, M., Clore, G. M. and Gronenborn, A. M. (1988a) Determination of three-dimensional structures of proteins from interproton distance data by hybrid distance geometrydynamical simulated annealing calculations. FEBS Lett. 229, 317-324.

Nilges, M., Clore, G. M. and Gronenborn, A. M. (1988b) Determination of three-dimensional structures of proteins from interproton distance data by dynamical simulated annealing from a random array of atoms. Circumventing problems associated with folding. FEBS Lett. 239, 129-136.

Nilges, M., Gronenborn, A. M., Brunger, A. T. and Clore, G. M. (1988c) Determination of three-dimensional structures of proteins by simulated annealing with interproton distance restraints. Application to crambin, potato carboxypeptidase inhibitor and barley serine proteinase inhibitor 2. Protein Eng. 2, 27-38

Okumura T., Takeuchi S., Motomura W., Yamda H., Egashira S. I., Asahi S., Kanatani A., Ihara M. and Kohgo Y. (2001) Reauirement of intact disulfide bonds in orexin-A induced stimulation of gastric acid secretion that is mediated by OX1 receptor activation. Biochem. Biophys. Res. Commun. 280, 976981.

Piotto, M., Saudek, V. and Sklenar, V. (1992) Gradient-tailored excitation for single-quantum NMR spectroscopy of aqueous solutions. J. Biomol. NMR, 2, 661-665.

Rance, M., Sorensen, O. W., Bodenhausen, G., Wagner, G., Ernst, 
R. R. and Wüthrich, K. (1983) Improved spectral resolution in COSY ${ }^{1}$ H-NMR spectra of proteins via double quantum filtering. Biochem. Biophys. Res. Commun., 117, 479-485.

Sakurai, T., Amemiya, A., Ishii, M., Matsuzaki, I., Chemelli, R. M., Tanaka, H., Williams, S. C., Richardson, J. A., Kozlowski, G. P., Wilson, S., Arch, J. R. S., Buckingham, R. E., Haynes, A. C., Carr, S. A., Annan, R. S., McNulty, D. E., Liu W. S., Terrett, J. A., Elshourbagy, N. A., Bergsma, D. J. and Yanagisawa, M. (1998) Orexins and orexin receptors: A family of hypothalamic neuropeptides and $\mathrm{G}$ protein-coupled receptors that regulate feeding behavior. Cell 92, 573-585.

Schwartz, M. W. (1998) The big picture of energy homeostasis gets a little bigger. Nat. Med. 4, 385-386.

Smith, E. M., Hughes, T. K., Hashemi, F. and Stefano, G. B. (1992) Immunosuppressive effects of corticotropin and melanotropin and their possible significance in human immunodeficiency virus infection. Proc. Natl. Acad. Sci. USA 89, 782-786.

Stephens, T. W., Basinski, M., Bristow, P. K., Bue-Valleskey, J. M., Burgett, S. G., Craft, L., Hale, J., Hoffmann, J., Hsiung, H. M., Kriauciunas, A., Mackellar, W., Rosteck, P. R., Schoner, B., Smith, D., Tinsley, F. C., Zhang, X.-Y. and Heiman, M. (1995) The role of neuropeptide $\mathrm{Y}$ in the antiobesity action of the obese gene product. Nature 377, 530-532.

Voisin, T., Rouet-Benzineb, P., Reuter, N. and Laburthe, M. (2003) Orexins and their receptors: structural aspects and role in peripheral tissues. Cell. Mol. Life. Sci. 60, 72-87.
Wagner, G., Braun, W., Havel., T. F., Schaumann, T., Go, N. and Wuthrich, K. (1987) Protein structures in solution by nuclear magnetic resonance and distance geometry: The polypeptide fold of the basic pancreatic trypsin inhibitor determined using two different algorithms, DISGEO and DISMAN. J. Mol. Biol. 196, 611-639.

Werner, K., Clemens, B., Paul, G. and Hans S. (1993) Determination of the disulphide bonding pattern in proteins by local and global analysis of nuclear magnetic resonance data. Application to flavoridin. J. Mol. Biol. 232, 897-906.

Wieland, H. A., Soll, R. M., Doods, H. N., Stenkamp, D., Hurnaus, R., Lammle, B. and Beck-Sickinger, A. G. (2002) The SK-N-MC cell line expresses an orexin binding site different from recombinant orexin 1-type receptor. Eur. J. Biochem. 269, 1128-1135.

Willie, J. T., Chemelli, R. M., Sinton, C. M. and Yanagisaw, M. (2001) To Eat or To Sleep? Orexin in the Regulation of Feeding and Wakefulness. Annu. Rev. Neura, Osci. 24, 429458.

Wishart, D. S., Sykes, B. D. and Richards, F. M. (1992) The chemical shift index: A fast and simple method for the assignment of protein secondary structure through NMR spectroscopy. Biochemistry 31, 1647-1651.

Zarjevski, N., Cusin, I., Vettor, R., Rohner-Jeanrenaud, F. and Jeanrenaud. (1993) Chronic intracerebroventricular neuropeptide$\mathrm{Y}$ administration to normal rats mimics hormonal and metabolic changes of obesity. Endocrinology 133, 1753-1758. 